\title{
ARTIKEL
}

\section{Bescherming van derdelandmigranten tegen arbeidsuitbuiting in de EU}

\author{
Gerrie Lodder
}

\section{Inleiding}

In 2018 en 2019 werden in zowel Duitsland ${ }^{1}$ als Frankrijk ${ }^{2}$ maatregelen aangekondigd om arbeidsmigratie van migranten van buiten de Europese Unie (EU) te reguleren en stimuleren. Het argument in beide landen was dat er als gevolg van de vergrijzing en economische ontwikkeling tekorten zijn op de arbeidsmarkt en dat het aanbod van arbeidskrachten uit eigen land en andere EU-landen niet voldoende is om in de vraag naar arbeidskrachten te voorzien. Ook in Nederland is er discussie over de vraag of Nederland behoefte heeft aan meer arbeidsmigranten en of deze vraag naar arbeidskrachten kan worden vervuld uit alleen het aanbod van binnen de EU. ${ }^{3}$ Hoewel er (toenemende) behoefte is aan arbeidsmigranten, worden deze migranten niet altijd goed behandeld. In 2015 verscheen het eerste rapport van de European Union Agency for Fundamental Rights (FRA) over ernstige vormen van arbeidsuitbuiting van migranten afkomstig uit zowel binnen als buiten de EU. ${ }^{4}$ In het FRA-rapport van 2015 wordt aangegeven dat het niet mogelijk is om het aantal slachtoffers van ernstige vormen van arbeidsuitbuiting vast te stellen. De FRA benoemt op basis van zijn onderzoek echter wel enkele sectoren waar een hoog risico op uitbuiting bestaat. Dit zijn de sectoren landbouw, bosbouw, visserij, bouw, horeca en sommige vormen van productie. ${ }^{5}$ Ook in de media wordt al jaren aandacht besteed aan arbeidsuitbuiting van migranten, met koppen als 'Moderne slavernij in Griekenland'6 of 'Noord-Koreaan klaagt Nederlands bedrijf aan om uitbuiting'. ${ }^{7}$ Het varieert dan van situaties waarin sprake is van bijvoorbeeld onderbetaling, slechte huisvesting of lange werkdagen,

1 Zie J. Eijsvoogel, Duitsland wordt soepeler met arbeidsmigratie, NRC 19 december 2018.

2 Zie D. Kool, Frankrijk scherpt asielbeleid fors aan en stelt quota in voor arbeidsmigratie, de Volkskrant 6 november 2019.

3 D66, Grip op arbeidsmigratie, 13 februari 2020, https://d66.nl/arbeidsmigratie/.

4 FRA, Severe labour exploitation-Workers moving within and into the European Union. States obligations and victims' rights, Luxemburg, 2015. In 2018 en 2019 verschenen er nog drie FRArapporten: Out of sight - Migrant women exploited in domestic work (2018), Protection migrant workers from exploitation in the EU - Boosting workplace inspections (2018), en Protection migrant workers from exploitation in the EU: Protecting Workers perspectives (2019).

$5 \quad$ FRA 2015, p.25.

6 T. Bruno, Moderne slavernij in Griekenland, de wereld morgen.be, 18 april 2013.

7 C. van der Veen, Noord-Koreaan klaagt Nederlands bedrijf aan om uitbuiting, NRC 8 november 2018. 
tot situaties waarin arbeidsmigranten onder dwang aan het werk worden gehouden.

De Covid-19-crisis zet de positie van arbeidsmigranten nog verder onder druk. ${ }^{8}$ Verschillende organisaties hebben de noodklok geluid over de situatie waarin arbeidsmigranten als gevolg van de pandemie verkeren. ${ }^{9}$ Tegelijkertijd zijn er zorgen over de beschikbaarheid van migranten voor het werk in met name de landen tuinbouw. ${ }^{10}$

De EU zet zich in voor de strijd tegen mensenhandel in het algemeen en arbeidsuitbuiting als een specifieke vorm van mensenhandel in het bijzonder. Dit heeft zich vertaald in een verbod op slavernij, dienstbaarheid, gedwongen en verplichte arbeid en mensenhandel. ${ }^{11}$ Meer concreet biedt de EU-richtlijn tegen mensenhandel bescherming tegen zowel seksuele uitbuiting als gedwongen arbeid. ${ }^{12}$

Ook in de EU-wetgeving ten aanzien van (arbeids)migratie van onderdanen van derde landen naar de EU (hierna: derdelanders) wordt aandacht besteed aan uitbuiting. ${ }^{13}$ Tegelijkertijd is het doel van deze wetgeving met name ook het 'zorgen voor een efficiënt beheer van migratiestromen' en preventie en bestrijding van illegale immigratie. ${ }^{14}$ De ontwikkeling van een gemeenschappelijk beleid voor migratie werd voorts voor een belangrijk deel ingegeven door economische overwegingen. ${ }^{15}$

Deze verschillende doelstellingen van het EU-migratiebeleid kunnen met elkaar botsen. Vanuit dit perspectief staat in dit artikel de vraag centraal wat de invloed is van EU-migratiewetgeving op de uitbuiting van arbeidsmigranten.

Op basis van de EU-wetgeving inzake migratie en de literatuur zijn er verschillende mogelijke effecten van migratiewetgeving op uitbuiting van migranten te destilleren. Ik heb deze verschillende effecten gecategoriseerd in drie verschillende manieren van invloed. De eerste categorie ziet op de wijze waarop de regule-

8 H. Grant, Migrant farm workers in Spain at crisis point, The Guardian 1 mei 2020; M. van den Eerenbeemt, Zwarte schoonmaker zit thuis zonder werk, en dus geld, de Volkskrant 26 maart 2020; B. Endedijk, Arbeidsmigranten in problemen door coronavirus, NRC 17 april 2020.

9 Zie bijvoorbeeld Group of experts on human trafficking, Dangers of the Coronavirus pandemic in relation to human trafficking, 2 april 2020; ILO, Protecting migrant workers during the COVID-19 pandemic, 30 april 2020; European Trade Union Confederation, Overlooked: migrant workers in the COVID19 crisis, 16 april 2020; Fairwork, Impact van corona op migranten in Nederland, 17 april 2020.

10 S. Carroll e.a., Covid-19 crisis stokes European tensions over migrant labour, The Guardian 11 mei 2020.

11 Artikel 5 Handvest van de grondrechten van de EU (Handvest).

12 Artikel 2 lid 3 Richtlijn 2011/36/EU.

13 Zie bijvoorbeeld Richtlijn 2014/36/EU, waar in de preambule wordt gesteld dat de richtlijn beoogt bij te dragen aan fatsoenlijke arbeidsvoorwaarden en leefomstandigheden voor seizoensarbeiders (overweging 7); Richtlijn (EU) 2016/801, waar in de preambule ten aanzien van au pairs wordt opgemerkt dat zij het risico lopen te worden uitgebuit (overweging 23); Richtlijn 2009/52/EG, die bescherming biedt aan illegaal verblijvende arbeidsmigranten.

14 Artikel 79 lid 1 VWEU.

15 Europese Raad, Het Haags Programma - Versterking van vrijheid, veiligheid en recht in de Europese Unie (2005/C 53/01), PbEU C53/4. 
ring van toelating en verblijf de kwetsbaarheid voor uitbuiting vergroot of vermindert. De tweede categorie omvat rechten voor derdelanders die zich in een uitbuitingssituatie bevinden. De derde categorie ten slotte, bestaat uit normen ten aanzien van de behandeling van derdelanders in migratiewetgeving waarmee uitbuiting wordt tegengegaan.

In dit artikel gaat het om de uitbuiting van derdelanders in een arbeidssituatie. Met de term arbeidsmigrant wordt een derdelander bedoeld die werkzaamheden verricht ongeacht het formele doel waarvoor deze persoon naar de EU is gekomen dan wel onder welke categorie deze persoon formeel valt.

Dit artikel is als volgt opgebouwd. In paragraaf 2 wordt de betekenis toegelicht die in dit artikel aan uitbuiting wordt gegeven. Paragraaf 3 geeft een overzicht van de wording van het EU-migratiebeleid voor derdelanders. In paragrafen 4, 5 en 6 worden achtereenvolgens de drie mogelijke manieren van invloed besproken. De conclusies volgen in paragraaf 7 .

\section{Het begrip uitbuiting nader bepaald}

Arbeidsuitbuiting is een diffuus begrip. Het wordt gebruikt als een containerbegrip voor diverse misstanden in werkgerelateerde situaties. Naast het begrip uitbuiting worden ook veel andere termen gebruikt, zoals mensenhandel, (moderne) slavernij, gedwongen arbeid of dienstbaarheid. Over de vraag wat uitbuiting of arbeidsuitbuiting inhoudt en hoe dit concept zich verhoudt tot andere concepten die duiden op vergelijkbare verschijnselen, is veel geschreven. ${ }^{16}$ Sommige concepten hebben wel een juridische definitie, zoals mensenhande ${ }^{17}$ of slavernij, ${ }^{18}$ maar het concept uitbuiting of arbeidsuitbuiting kent geen formele juridische definitie. Ook de concepten die wel een formele definitie hebben, zijn niet eenduidig te interpreteren, omdat de afzonderlijke bestanddelen van de definitie (veel) ruimte laten voor invulling. Uitbuiting zou gedefinieerd kunnen worden als arbeid die niet voldoet aan de norm van 'decent work'. De Internationale Arbeidsorganisatie

16 Zie bijvoorbeeld P. Campana \& F. Varese, Exploitation in Human Trafficking and Smuggling, European Journal on Criminal Policy and Research 2016, 22, p. 89; C. Rijken, Legal Approaches to Combating the Exploitation of Third-Country National Seasonal Workers, The International Journal of Comparative Labour Law and Industrial Relations 2015, 4, p. 431-452.

17 Mensenhandel is gedefinieerd als the recruitment, transportation, transfer, harbouring or receipt of persons, by means of the threat or use of force or other forms of coercion, of abduction, of fraud, of deception, of the abuse of power or of a position of vulnerability or of the giving or receiving of payments or benefits to achieve the consent of a person having control over another person, for the purpose of exploitation. Exploitation shall include, at a minimum, the exploitation of the prostitution of others or other forms of sexual exploitation, forced labour or services, slavery or practices similar to slavery, servitude or the removal of organs', in het Optional Protocol to Prevent, Suppress and Punish Trafficking in Persons, Especially Women and Children to the UN Convention against Transnational Crime 2000. Datum inwerkingtreding: 25 december 2003.

18 Slavernij is gedefinieerd in het Verdrag inzake de slavernij (1926) in artikel 1 lid 1: 'Slavery is the status or condition of a person over whom any or all of the powers attaching to the right of ownership are exercised.' 
(IAO) timmert al jaren aan de weg met de agenda voor 'decent work' (fatsoenlijk of waardig werk). ${ }^{19}$ Dit begrip wordt wereldwijd geaccepteerd als de standaard voor 'fatsoenlijk werk'. Werk moet voldoen aan de criteria waardigheid, gelijkheid, een eerlijk inkomen en veiligheid. Deze criteria worden echter niet gedefinieerd. ${ }^{20}$ Bij de definiëring van het begrip uitbuiting spelen twee componenten een rol: een vorm van slechte behandeling en een vorm van dwang. De reikwijdte van het begrip uitbuiting varieert enorm op basis van een ruime of juist restrictieve invulling die aan deze bestanddelen wordt gegeven. Gaat het bij een 'slechte behandeling' om uitwassen zoals het laten werken zonder of tegen een zeer geringe beloning, het verplichten tot extreem lange werkdagen, extreem slechte werkomstandigheden, of is ook ongelijke behandeling te kwalificeren als uitbuiting? De variaties in vormen van slechte behandeling en de ruimte tussen de uitersten is gigantisch groot. Hetzelfde geldt voor het bestanddeel 'dwang'. In het kader van het definiëren van begrippen als gedwongen arbeid en mensenhandel wordt onder dwang niet alleen verstaan het gebruik van fysieke dwang in de vorm van geweld, maar ook psychologische vormen van dwang, het innemen van documenten, het beperken van de bewegingsvrijheid, het geven van misleidende informatie en 'misbruik maken van een kwetsbare positie'. ${ }^{21}$ Daarnaast is het de vraag of er altijd sprake moet zijn van dwang om te kunnen spreken van uitbuiting of dat zogenoemde consensuele uitbuiting ook als uitbuiting valt te kwalificeren.

Hoewel er voor een strafrechtelijke afbakening van arbeidsuitbuiting een grens getrokken moet worden tussen situaties die wel en situaties die niet kwalificeren als een vorm van uitbuiting, zijn in de praktijk beide bestanddelen van uitbuiting te plaatsen op een continuüm. In dit artikel gaat het niet om de bestraffing van daders, maar om de bescherming van migranten tegen uitbuiting. Daarom wordt het hele spectrum van uitbuitingssituaties meegenomen.

Arbeidsuitbuiting van migranten wordt in het kader van dit artikel gedefinieerd als een situatie waarin sprake is van een slechte behandeling van een arbeidsmigrant in absolute of relatieve zin (ongelijke behandeling) en waarbij sprake kan zijn van dwang, maar dit is geen noodzakelijke voorwaarde.

\section{De regulering van migratie van derdelanders naar de EU}

Het Verdrag van Amsterdam (1997) creëerde de bevoegdheid voor de EU om richtlijnen en verordeningen op het gebied van migratie van derdelanders naar de EU te ontwikkelen. ${ }^{22}$ Tegenwoordig worden de toelating tot het EU-grondgebied,

19 Zie bijvoorbeeld www.ilo.org/asia/decentwork/lang--en/index.htm.

20 Een nadere invulling van deze begrippen kan gevonden worden in de diverse ILO-conventies ten aanzien van gedwongen arbeid (nrs. 29 en 105), kinderarbeid (nrs. 138 en 182), vrijheid van vereniging en collectieve arbeidsovereenkomsten (nrs. 87 en 98), gelijke beloning en discriminatie (nrs. 100 en 111).

21 Zie bijvoorbeeld ILO, Indicators of forced labour, Special Action Programme to combat Forced Labour, en de definitie van mensenhandel uit het Palermo-protocol. 
de voorwaarden voor verschillende soorten verblijf, verblijfsrechten en terugkeer geregeld door het Unierecht. Ook op het gebied van arbeidsmigratie zijn diverse richtlijnen tot stand gekomen.

Voor dit artikel is met name de regulering van arbeidsmigratie relevant. Daarnaast is van belang welke andere kanalen voor legale migratie toegankelijk zijn en onder welke voorwaarden migranten die zijn toegelaten voor een ander doel dan het verrichten van arbeid, toegang hebben tot de arbeidsmarkt.

De regulering van migratie van derdelanders naar de EU gaat uit van een fundamenteel ander beginsel dan de intra-EU-migratie van Unieburgers. Voor Unieburgers geldt als basisbeginsel het recht vrij te reizen en verblijven op het grondgebied van de Unie en het recht om te werken in loondienst of als zelfstandige en diensten te verrichten. ${ }^{23}$ Deze vrijheden kunnen aan bepaalde voorwaarden worden gebonden, maar volgens vaste jurisprudentie van het Hof van Justitie van de Europese Unie (HvJ EU), moeten beperkingen van de vrijheden restrictief worden toegepast. Daarnaast geldt ten aanzien van deze vrijheden een verbod op discriminatie naar nationaliteit. ${ }^{24}$ Voor derdelanders die toegang en verblijf op het grondgebied van de Unie zoeken, geldt het omgekeerde beginsel: zij hebben geen recht op toegang en verblijf, tenzij wordt voldaan aan bepaalde voorwaarden.

De grondslag voor de diverse maatregelen die op het gebied van migratie van derdelanders zijn vastgesteld, is te vinden in artikelen 78 en 79 van het Verdrag betreffende de werking van de Europese Unie (VWEU). Artikel 78 VWEU regelt de bevoegdheid om maatregelen op het gebied van asielmigratie vast te stellen, en artikel 79 VWEU legt de grondslag voor regulering van overige migratie, zoals arbeidsmigratie.

Twintig jaar nadat de eerste voorstellen voor de regulering van migratie op grond van deze bepalingen door de Europese Commissie (EC) zijn gedaan, is er nu een stelsel van richtlijnen dat ziet op verschillende fases van migratie. Op het gebied van toegang zijn met name twee verordeningen van belang die de voorwaarden voor toegang en kort verblijf (dat wil zeggen verblijf van maximaal drie maanden) reguleren. Dit zijn de Schengengrenscode ${ }^{25}$ en de Visumcode. ${ }^{26}$ De regulering van verblijf van langer dan drie maanden is per verblijfsdoel uitgewerkt. De Gezinsherenigingsrichtlijn is de eerste richtlijn die in dit kader tot stand is gekomen. ${ }^{27}$ Deze richtlijn bepaalt de voorwaarden waaronder gezinsleden van derdelanders met een verblijfsvergunning in een van de lidstaten van de EU een recht op gezinshereniging hebben. Op het gebied van asiel zijn enkele richtlijnen en een verordening tot stand gekomen. In het kader van dit artikel is de Opvangrichtlijn

23 Zie artikelen 20, 21, 45, 49 en 56 VWEU.

24 Zie artikel 45 lid 2 VWEU en artikelen 49 en 57 VWEU.

25 Verordening (EU) 2016/399 van het Europees Parlement en de Raad van 9 maart 2016 betreffende een Uniecode voor de overschrijding van de grenzen door personen (Schengengrenscode).

26 Verordening (EG) nr. 810/2009 van het Europees Parlement en de Raad van 13 juli 2009 tot vaststelling van een gemeenschappelijke visumcode (Visumcode).

27 Richtlijn 2003/86/EG van de Raad van 22 september 2003 inzake het recht op gezinshereniging. 
van belang, die regels stelt ten aanzien van de opvang van asielzoekers tijdens de aanvraagprocedure. ${ }^{28}$ Verder is de Kwalificatierichtlijn relevant, die bepaalt wat de gronden zijn voor toekenning van een verblijfstitel voor internationale bescherming en welke rechten een asielzoeker aan wie bescherming is verleend, heeft. ${ }^{29}$ Er bestaan diverse richtlijnen die een specifieke categorie van arbeid of uitwisseling reguleren. In de Onderzoekers- en studentenrichtlijn wordt naast de regulering van verblijf voor wetenschappelijk onderzoek en studie ook het verblijf voor au pairs, scholierenuitwisseling, vrijwilligerswerk en stage geregeld. ${ }^{30} \mathrm{Er}$ is een richtlijn voor de toelating van hooggekwalificeerde arbeid (Blauwe Kaartrichtlijn ${ }^{31}$ ), voor overplaatsing binnen een onderneming (ICT-richtlijn ${ }^{32}$ ) en voor seizoensarbeiders (Richtlijn Seizoensarbeid ${ }^{33}$ ). Verder is er een richtlijn die procedures voor het aanvragen van een gecombineerde vergunning voor verblijf en arbeid vaststelt en de rechten van arbeidsmigranten na toelating regelt (Richtlijn Verblijf en werk ${ }^{34}$ ).

De toegang tot het recht op permanent verblijf en de rechten van langdurig verblijvende derdelanders zijn geregeld in de Richtlijn Langdurig ingezetenen. ${ }^{35}$ De procedures met betrekking tot terugkeer van irregulier verblijvende derdelanders zijn neergelegd in de Terugkeerrichtlijn. ${ }^{36}$

28 Richtlijn 2013/33/EU van het Europees Parlement en de Raad van 26 juni 2013 tot vaststelling van normen voor de opvang van verzoekers om internationale bescherming.

29 Richtlijn 2011/95/EU van het Europees Parlement en de Raad van 13 december 2011 inzake normen voor de erkenning van onderdanen van derde landen of staatlozen als personen die internationale bescherming genieten, voor een uniforme status voor vluchtelingen of voor personen die in aanmerking komen voor subsidiaire bescherming, en voor de inhoud van de verleende bescherming.

30 Richtlijn 2016/801/EU van het Europees Parlement en de Raad van 11 mei 2016 betreffende de voorwaarden voor toegang en verblijf van derdelanders met het oog op onderzoek, studie, stages, vrijwilligerswerk, scholierenuitwisseling, educatieve projecten of au-pairactiviteiten (herschikking).

31 Richtlijn 2009/50/EG van de Raad van 25 mei 2009 betreffende de voorwaarden voor toegang en verblijf van onderdanen van derde landen met het oog op een hooggekwalificeerde baan.

32 Richtlijn 2014/66/EU van het Europees Parlement en de Raad van 15 mei 2014 betreffende de voorwaarden voor toegang en verblijf van onderdanen van derde landen in het kader van een overplaatsing binnen een onderneming.

33 Richtlijn 2014/36/EU van het Europees Parlement en de Raad van 26 februari 2014 betreffende de voorwaarden voor toegang en verblijf van onderdanen van derde landen met het oog op tewerkstelling als seizoenarbeider.

34 Richtlijn 2011/98/EU van het Europees Parlement en de Raad van 13 december 2011 betreffende één enkele aanvraagprocedure voor een gecombineerde vergunning voor onderdanen van derde landen om te verblijven en te werken op het grondgebied van een lidstaat, alsmede inzake een gemeenschappelijk pakket rechten voor werknemers uit derde landen die legaal in een lidstaat verblijven.

35 Richtlijn 2003/109/EG van de Raad van 25 november 2003 betreffende de status van langdurig ingezeten onderdanen van derde landen.

36 Richtlijn 2008/115/EG van het Europees Parlement en de Raad van 16 december 2008 over gemeenschappelijke normen en procedures in de lidstaten voor de terugkeer van onderdanen van derde landen die illegaal op hun grondgebied verblijven. 
Ten slotte is de Werkgeverssanctierichtlijn ${ }^{37}$ relevant. Deze richtlijn is vooral een instrument in de strijd tegen irreguliere migratie, maar biedt tegelijkertijd bescherming aan arbeidsmigranten zonder rechtmatig verblijf.

In de paragrafen 4, 5, en 6 worden de effecten van de EU-migratiewetgeving op de in de inleiding genoemde drie manieren van invloed op uitbuiting geanalyseerd.

\section{Regulering verblijfsrecht}

De wijze waarop het verblijfsrecht voor derdelanders is gereguleerd, kan de kwetsbaarheid van migranten voor uitbuiting versterken of juist verminderen. ${ }^{38}$ In deze paragraaf wordt de EU-migratieregelgeving getoetst aan de mogelijke effecten van de regulering van het verblijfsrecht op de kwetsbaarheid voor uitbuiting. De deelvraag die hier wordt beantwoord, is of de wijze waarop de toelating en het verblijf van derdelanders in het EU-recht zijn geregeld, bijdraagt aan de bescherming van derdelanders tegen arbeidsuitbuiting, of hieraan juist afbreuk doet. Voor de beantwoording van deze vraag wordt eerst gekeken naar de wijze waarop toegang tot het EU-grondgebied is geregeld (4.1) en daarna naar hoe de verkrijging en het intrekken van de diverse vormen van verblijf zijn gereguleerd (4.2). Vervolgens komt aan bod of een derdelander mag werken (4.3) en de mogelijkheid heeft om van werkgever te wisselen (4.4). Ten slotte wordt besproken hoe de verblijfsduur is geregeld en of er uitzicht is op permanent verblijf (4.5).

\subsection{Toegang tot het EU-grondgebied}

De EU heeft strenge voorwaarden voor toegang en een strikte grenscontrole aan de buitengrenzen van de EU om deze voorwaarden te handhaven. ${ }^{39}$ De laatste decennia zijn zowel de regels voor het verkrijgen van toegang als de instrumenten bij grenscontroles, zoals het inzetten van radarcontroles, hogere hekken en preboardingcontroles door vliegmaatschappijen, aangescherpt. ${ }^{40}$ Vanuit EUperspectief moet grenstoezicht bijdragen aan de bestrijding van illegale immigratie en mensenhandel. ${ }^{41}$ Door verschillende auteurs wordt echter gewezen op het vergroten van de kwetsbaarheid van migranten voor mensenhandel en mensensmokkel door de invoering en versterking van strenge grenscontroles. ${ }^{42}$

37 Richtlijn 2009/52/EG van het Europees Parlement en de Raad van 18 juni 2009 tot vaststelling van minimumnormen inzake sancties en maatregelen tegen werkgevers van illegaal verblijvende onderdanen van derde landen.

38 Zie de onderzoeken van FRA naar arbeidsuitbuiting van migranten van 2015 en 2019. Het gaat in deze rapporten om zowel EU-migranten als derdelanders.

39 E. Guild \& S. Carrera, EU Borders and Their Controls: Preventing Unwanted Movement of People in Europe?, CEPS Essays 2013, 6.

40 Guild \& Carrera 2013, p. 4.

41 Zie bijvoorbeeld preambule 6 Schengengrenscode.

42 K. Hailbronner, Immigration and Asylum Law and Policy of the European Union, Den Haag: Kluwer Law International 2000, p. 163; N. Nanopoulos, E. Guild \& K.T. Weatherhead, Securitisation of Borders and the UN's Global Compact on Safe, Orderly and Regular Migration, Queen Mary University of London, School of Law Legal Studies Research Paper 2018, 270, p. 13. 
In het kader van dit artikel gaat het om het juridisch kader dat toegang van derdelanders tot het EU-grondgebied regelt. Hierna worden drie voorwaarden uitgelicht die het derdelanders moeilijk kunnen maken om legaal toegang te krijgen tot het grondgebied van de EU.

De eerste voorwaarde heeft betrekking op het verkrijgen van toegang voor kort verblijf. Kort verblijf wil in deze context zeggen een verblijf van niet meer dan 90 dagen. De voorwaarden zijn opgenomen in de Schengengrenscode. Deze voorwaarden zijn in grote lijnen: beschikken over een geldig reisdocument en indien nodig een visum, beschikken over voldoende middelen van bestaan voor het voorgenomen reisdoel en de reisduur, en geen gevaar opleveren voor de openbare orde. ${ }^{43}$ Uit de formulering van artikel 6 Schengengrenscode kan worden afgeleid dat als aan de voorwaarden voor een kort verblijf is voldaan, toegang wordt verleend. In beginsel biedt deze bepaling dus een duidelijk kader voor het recht op toegang. De visumcode werpt echter een drempel op voor derdelanders voor wie een visumplicht geldt. De visumplicht geldt voor de meeste nationaliteiten, waaronder alle landen waar veel vluchtelingen vandaan komen $^{44}$ en landen die economisch minder ontwikkeld zijn. ${ }^{45}$ Op grond van de Visumcode moet bij het onderzoek van een visumaanvraag 'bijzondere aandacht worden besteed aan de beoordeling of de aanvrager een risico op illegale immigratie vertoont (...) en of de aanvrager voornemens is het grondgebied van de lidstaten te verlaten vóór het verstrijken van het aangevraagde visum' ${ }^{46}$ Deze voorwaarde blijkt de lidstaten in de praktijk een ruime beoordelingsvrijheid te geven om visumaanvragen te weigeren. ${ }^{47}$ Uit onderzoek blijkt dat dit voor Nederland een van de meest voorkomende redenen is voor de weigering van een visum. ${ }^{48}$

De tweede maatregel ziet op het verkrijgen van toegang voor verblijf van langer dan 90 dagen. De toegangsvoorwaarden van de Schengengrenscode zijn alleen van toepassing op kort verblijf. Als het gaat om het verlenen van toegang voor verblijf van langer dan 90 dagen zijn andere regels van toepassing. De voorwaarden van artikel 6 Schengengrenscode mogen geen reden zijn om de toegang te weigeren aan een migrant die asiel zoekt op het grondgebied van de EU of aan een migrant aan wie toestemming voor verblijf van langer dan drie maanden is verleend door een van de lidstaten. ${ }^{49}$ Voor migranten die nog geen verblijfsrecht hebben, geldt echter op grond van de EU-migratierichtlijnen, met uitzondering van de asielrichtlijnen, het principe dat een aanvraag alleen kan worden ingediend als de aanvrager zich buiten het grondgebied van de EU bevindt. De EU-

43 Zie artikel 6 Verordening (EU) 2016/399.

44 L. Ansems de Vries \& E. Guild, Seeking refuge in Europe: spaces of transit and the violence of migration management, Journal of Ethnic and Migration Studies 2019, 12, p. 2156-2166.

45 Bijlage bij Verordening (EG) 539/2001, laatst gewijzigd bij Verordening (EU) 2017/850.

46 Artikel 21 lid 1 Verordening (EG) nr. 810/2009.

47 HvJ EU (Grote Kamer) 19 december 2013, C-84/12 (Koushkaki), JV 2014/57. Zie ook M.I. Vennik \& E. Schoneveld, Gebreken van de procedure voor het visum kort verblijf, Asiel en Migrantenrecht 2018, 8, p. 356-362.

48 M. van Benthem \& B. Tieben, Toegangswaarde. De maatschappelijke kosten en baten van het Schengen-visumbeleid voor Nederland, Amsterdam: SEO Economisch Onderzoek 2018, p. 28. 
richtlijnen betreffende werk hebben het toepassingsbereik expliciet beperkt tot derdelanders die buiten het grondgebied van de EU-lidstaten verblijven. ${ }^{50}$ Uit de totstandkomingsgeschiedenis van de Richtlijn Seizoensarbeid blijkt dat lidstaten geen mogelijkheid wilden bieden aan een irregulier verblijvende derdelander om een aanvraag op het grondgebied in te dienen. ${ }^{51}$ Voor derdelanders die verzoeken om gezinsherenging is het een procedurele voorwaarde dat gezinsleden buiten het grondgebied van de lidstaat verblijven. ${ }^{52}$ Als gevolg van deze voorwaarde kan een derdelander in beginsel alleen toegang krijgen tot het EU-grondgebied voor een verblijf langer dan 90 dagen als hij een verblijfsvergunning aanvraagt terwijl hij buiten het grondgebied van de EU verblijft en nadat de aanvraag voor een verblijfsvergunning is ingewilligd. De voorwaarde 'verblijf buiten het grondgebied' houdt in dat een aanvraag ingediend door een op het grondgebied van een van de lidstaten van de EU irregulier verblijvende migrant kan worden afgewezen.

Het laatste voorbeeld van een maatregel die het legaal toegang krijgen tot het grondgebied van de EU bemoeilijkt, is een uitvloeisel van de Terugkeerrichtlijn. De Terugkeerrichtlijn heeft een inreisverbod geïntroduceerd voor derdelanders die illegaal op het grondgebied van een van de lidstaten van de EU zijn aangetroffen. ${ }^{53}$ Het kan hierbij gaan om derdelanders die nooit legaal verblijf hebben gehad of om derdelanders die na een eerder legaal verblijf niet tijdig het grondgebied van de Unie hebben verlaten. Met een inreisverbod is het in principe onmogelijk om toestemming te krijgen om het EU-grondgebied gedurende een bepaalde periode te betreden.

\subsection{Voorwaarden voor verkrijging en gronden voor verlies}

De regulering van verblijf van langer dan 90 dagen is neergelegd in verschillende richtlijnen, die ieder eigen voorwaarden voor toelating en gronden voor verlies kennen.

In tegenstelling tot de regulering van kort verblijf, waarbij in beginsel verblijf wordt toegestaan als aan de voorwaarden is voldaan, kent de regulering van verblijf voor langer dan 90 dagen voor enkele verblijfscategorieën meer discretionaire bevoegdheid toe aan de lidstaten. Gezinsherenigers, ${ }^{54}$ asielzoekers $^{55}$ en studenten ${ }^{56}$ hebben een recht op toelating als aan de voorwaarden in de richtlijn is voldaan. Voor andere richtlijnen geldt het beginsel dat als aan de voorwaarden is voldaan, een verblijfsvergunning wordt verleend. ${ }^{57}$ Echter, alle richtlijnen met betrekking tot specifieke vormen van werk stellen de lidstaten in staat om rekening te houden met de nationale situatie op de arbeidsmarkt en om een aan-

50 Zie artikel 3 Richtlijn 2009/50 /EG; artikel 2 lid 1 Richtlijn 2014/36/EU; artikel 2 lid 1 Richtlijn 2014/66/EU.

51 Zie J. Fudge \& P. Herzfeld Olsson, The seasonal workers directive, European Journal of Migration and Law 2014, 16, p. 448.

52 Artikel 5 lid 3 Richtlijn 2003/86/EG.

53 Artikel 11 Richtlijn 2008/115/EG.

54 Artikelen 1 en 13 Richtlijn 2003/86/EG.

55 Artikel 24 Richtlijn 2011/95/EU.

56 Artikel 6 Richtlijn 2016/801/EU.

57 Zie bijvoorbeeld artikel 4 lid 3 Richtlijn 2011/98/EU; artikel 5 lid 3 Richtlijn 2016/801/EU. 
vraag op deze grond af te wijzen. ${ }^{58}$ Deze bepalingen zijn gebaseerd op artikel 79 lid 5 VWEU, dat de lidstaten het recht verleent om 'zelf te bepalen hoeveel onderdanen van derde landen, afkomstig uit derde landen, tot hun grondgebied worden toegelaten teneinde daar al dan niet in loondienst arbeid te verrichten'. Dat houdt in dat ook al voldoet een derdelander aan de voorwaarden voor toelating, zoals het hebben van een baan waarmee voldoende inkomsten worden verworven, de aanvraag voor een verblijfsvergunning toch kan worden afgewezen. Vanuit het perspectief van de arbeidsmigrant is deze bevoegdheid van de lidstaten een factor die de toegang tot het verkrijgen van een vergunning als arbeidsmigrant bemoeilijkt.

Voor alle verblijfstypes, met uitzondering van een verblijf op basis van internationale bescherming, is het hebben van voldoende middelen van bestaan een voorwaarde voor het verkrijgen en behouden van een verblijfsvergunning. Deze voorwaarde kan de derdelander afhankelijk maken van de werkgever. ${ }^{59}$

Ook andere gronden waarop een verblijfsvergunning kan worden geweigerd of ingetrokken, kan het verblijfsrecht onzeker maken. Een onzekere verblijfsstatus wordt door slachtoffers van uitbuiting genoemd als een belangrijke risicofactor voor uitbuiting. ${ }^{60}$

Het verblijfsrecht van de houders van een werkgerelateerde verblijfsvergunning is afhankelijk van het hebben van een arbeidsovereenkomst. Als de arbeidsovereenkomst wordt beëindigd, is dit een reden om het verblijfsrecht te beëindigen. De Seizoensarbeidersrichtlijn en de ICT-richtlijn bevatten naast deze intrekkingsgrond een reeks vrijwel identieke gronden voor het afwijzen en het intrekken (of weigering om te verlengen) van een verblijfsvergunning. Deze gronden lijken met name bedoeld om malafide werkgevers aan te pakken en illegale immigratie te bestrijden. Als de werkgever of de gastentiteit is bestraft voor zwart werk of illegale tewerkstelling, wijzen de lidstaten de vergunning af dan wel trekken de lidstaten de verblijfsvergunning in. ${ }^{61}$ Deze bepaling is dwingend geformuleerd. Niet is gespecificeerd hoever terug in de tijd een veroordeling van de werkgever aanleiding kan zijn de vergunning af te wijzen dan wel in te trekken. Tegelijkertijd bieden de woorden in voorkomend geval of indien nodig ruimte aan lidstaten om de vergunning niet in te trekken. Omdat echter onduidelijk is wat hiermee wordt bedoeld, is het de vraag of een derdelander wiens vergunning op deze grond wordt ingetrokken enige bescherming aan deze bepaling kan ontlenen. Verder kunnen lidstaten de vergunning afwijzen of intrekken wanneer de werkgever of de gastentiteit zijn wettelijke verplichtingen met betrekking tot sociale zekerheid, (Richtlijn Seizoensarbeid); artikel 6 Richtlijn 2014/66 /EU (ICT-richtlijn); artikel 6 Richtlijn 2016/801/EU (Onderzoekers- en studentenrichtlijn).

59 FRA 2019, p. 68-69.

60 FRA 2019, p. 67.

61 Artikel 8 lid 2 (a) en artikel 9 lid 2 (a) Richtlijn 2014/36/EU (Richtlijn Seizoensarbeid); artikel 7 lid 2 en artikel 8 lid 2 Richtlijn 2014/66/EU (ICT-richtlijn). 
belastingen, arbeidsrechten of arbeidsvoorwaarden niet is nagekomen. ${ }^{62}$ In het geval van seizoensarbeiders kan het enkele feit dat de werkgever zijn verplichtingen uit hoofde van de arbeidsovereenkomst niet is nagekomen, een reden zijn om de verblijfsvergunning in te trekken. ${ }^{63}$ De richtlijn voor onderzoekers en studenten bevat vergelijkbare bepalingen voor het weigeren of intrekken van de vergunning van au pairs, vrijwilligers en scholieren. ${ }^{64}$ De bepalingen zijn voor deze categorieën facultatief geformuleerd. Alle werknemers van de betrokken werkgever die op grond van de Seizoensarbeidersrichtlijn, de ICT-richtlijn of de Onderzoekers- en studentenrichtlijn een vergunning hebben gekregen, kunnen hun verblijfsvergunning verliezen, ook als zij niet illegaal tewerk zijn gesteld of de werkgever ten aanzien van hen de arbeidsvoorwaarden wel is nagekomen. Zeker waar het gaat om seizoensarbeiders geven deze verliesgronden daarom aanleiding tot bezorgdheid. ${ }^{65}$

\subsection{Toegang tot werk}

Voor veel migranten is economische noodzaak een van de redenen om slechte werkomstandigheden te accepteren. ${ }^{66}$ Beperking van toegang tot de arbeidsmarkt voor legaal verblijvende derdelanders kan migranten nopen illegaal werk te aanvaarden. Dit maakt niet alleen een illegaal verblijvende derdelander kwetsbaar voor uitbuiting, maar ook een derdelander die op grond van zijn verblijfsvergunning niet mag werken. Het is daarom van belang of een derdelander op grond van zijn verblijfsvergunning toegang heeft tot de arbeidsmarkt.

De meeste richtlijnen voorzien in een (beperkt) recht om te werken voor migranten die legaal op het grondgebied van de lidstaat verblijven. Asielzoekers die in afwachting zijn van een beslissing over een asielverzoek krijgen uiterlijk negen maanden na de datum van indiening van het verzoek om internationale bescherming toegang tot de arbeidsmarkt indien geen beslissing in eerste aanleg wordt genomen en de vertraging niet is te wijten aan de asielzoeker. ${ }^{67} \mathrm{Het}$ is onduidelijk of hier een afdwingbaar recht op toegang tot de arbeidsmarkt wordt verleend. De lidstaten kunnen enerzijds voorwaarden stellen aan het verlenen van toegang tot de arbeidsmarkt, maar moeten anderzijds ervoor zorgen dat asielzoekers effectieve toegang tot de arbeidsmarkt hebben. De tekst van de richtlijn is op dit punt verwarrend. Verder mogen lidstaten om redenen van arbeidsmarktbeleid prioriteit geven aan EU-/EER-burgers en onderdanen van derde landen die legaal op het

62 Artikel 8 lid 4 (a) en artikel 9 lid 3 (b) Richtlijn 2014/36/EU (Richtlijn Seizoensarbeid); artikel 7 lid 3 (a) en artikel 8 lid 5 (b) Richtlijn 2014/66/EU (ICT-richtlijn) (deze bepaling is facultatief geformuleerd).

63 Artikel 9 lid 3 (c) Richtlijn 2014/36/EU.

64 Zie artikel 20 lid 2 en artikel 21 lid 2.

65 Zie bijvoorbeeld commissie-Meijers, Note on the proposal for a Directive on the conditions of entry and residence of third country nationals for the purposes of seasonal employment, CM1113, 31 oktober 2011, p. 3; Fudge \& Herzfeld Olsson 2014, p. 453-455; A. Lazorowicz, A success story for the EU and seasonal workers' rights without reinventing the wheel, EPC, Policy Brief 28 maart 2014, p. 4.

66 FRA 2015, p. 45-46; FRA 2019, p. 70.

67 Artikel 15 lid 1 Richtlijn 2013/33/EU (Opvangrichtlijn). 
grondgebied verblijven. ${ }^{68}$ Op grond van het EU-recht bestaat er geen recht op toegang tot de arbeidsmarkt in de eerste negen maanden na indiening van een asielverzoek. Onmiddellijk nadat internationale bescherming is verleend, geven de lidstaten volledige toegang tot de arbeidsmarkt. ${ }^{69}$

Gezinsmigranten hebben op grond van de Gezinsherenigingsrichtlijn op dezelfde manier als de sponsor (het familielid bij wie zij verblijven) recht op toegang tot werkzaamheden in loondienst of als zelfstandige. ${ }^{70}$ Een van de voorwaarden voor gezinshereniging die lidstaten aan gezinshereniging kunnen stellen, is dat de sponsor moet zorgen voor voldoende inkomsten. Dit houdt in dat over het algemeen de sponsor toegang zal hebben tot de arbeidsmarkt, en daarmee dus ook de overkomende gezinsleden. De Gezinsherenigingsrichtlijn bevat twee beperkingen voor het recht op toegang tot werk. Ten eerste kan de toestemming aan familieleden om een activiteit als werknemer of zelfstandige uit te oefenen met maximaal twaalf maanden worden uitgesteld om redenen van arbeidsmarktbeleid. Ten tweede kunnen afhankelijke ouders en volwassen ongehuwde kinderen die zijn toegelaten met het oog op hun gezondheid, worden uitgesloten van het recht op toegang tot werkzaamheden in loondienst of als zelfstandige. Nu het hier gaat om gezinsleden die op grond van hun afhankelijkheid van de sponsor zijn toegelaten, kan dit de uitsluiting van toegang tot de arbeidsmarkt verklaren. Tegelijkertijd kan deze beperking ook de afhankelijkheid vergroten.

Dezelfde dubbelzinnigheid met betrekking tot de toegang tot de arbeidsmarkt van asielzoekers is van toepassing op studenten. Hoewel studenten recht hebben op een activiteit in loondienst of als zelfstandige van ten minste 15 uur per week, kunnen lidstaten ook ten aanzien van deze categorie migranten rekening houden met de situatie op de arbeidsmarkt. ${ }^{71}$ In het voorstel voor de Onderzoekers- en studentenrichtlijn stelt de Europese Commissie dat de beperking van toegang van studenten tot de arbeidsmarkt 'dient te gebeuren op evenredige wijze, zodat het recht om te werken niet systematisch wordt beknot'. ${ }^{72}$

Voor studenten die een bijbaantje hebben om in hun kosten van levensonderhoud te voorzien kan een overschrijding van de maximale tijd die zij mogen werken reden zijn om de verblijfsvergunning in te trekken. ${ }^{73}$

Derdelanders die een vergunning als langdurig ingezetene hebben gekregen, hebben gelijke toegang tot activiteiten als werknemer en zelfstandige als de eigen burgers. De enige uitzondering heeft betrekking op werk dat deelname aan de uitoefening van het openbaar gezag behelst. ${ }^{74}$ Voor de langdurig ingezetene die van zijn recht op intra-EU-mobiliteit gebruik wil maken om een economische activiteit uit te oefenen in een andere lidstaat, kunnen de lidstaten de toegang tot de 
arbeidsmarkt wel beperken en daarmee de mogelijkheden voor intra-EUmobiliteit. ${ }^{75}$ In dat opzicht is de arbeidsmarktpositie van een langdurig ingezetene dus nog niet gelijk aan die van een EU-burger.

\subsection{Het recht om van werkgever te veranderen}

Een volgend aspect met betrekking tot de kwetsbaarheid voor uitbuiting ziet op het recht om van werkgever te wisselen. Voor alle richtlijnen die een specifieke categorie van arbeid reguleren is een geldig arbeidscontract of bindend aanbod een voorwaarde voor het verkrijgen en behoud van een verblijfsvergunning. Voor derdelanders die een verblijfsvergunning hebben verkregen op basis van een van deze richtlijnen voor arbeidsmigratie, is van belang in welke mate zij gebonden zijn aan een werkgever. Gebondenheid aan een werkgever maakt een migrant afhankelijk van die werkgever en daarmee kwetsbaar voor uitbuiting. ${ }^{76}$

De seizoensarbeider is gemachtigd om ten minste eenmaal zijn verblijf bij dezelfde werkgever of een andere werkgever te verlengen, zolang de maximale duur van zijn verblijf niet wordt overschreden. ${ }^{77}$ Deze mogelijkheid moet het risico op misbruik dat ontstaat als een werknemer gebonden is aan één werkgever, verkleinen. ${ }^{78}$ Tegelijk stelt de preambule echter: 'De aan de seizoenarbeider geboden mogelijkheid om door een andere werkgever tewerkgesteld te worden onder de in deze richtlijn vastgelegde voorwaarden mag niet inhouden dat de betrokkene werk kan zoeken op het grondgebied van de lidstaat terwijl hij werkloos is. ${ }^{79}$ De seizoensarbeider die van werkgever wil veranderen, bijvoorbeeld omdat hij zich in een uitbuitingssituatie bevindt, zal dus eerst een andere werkgever moeten vinden voordat hij bij zijn oorspronkelijke werkgever vertrekt.

De positie van de au pair is onduidelijk. De au pair is voor haar/zijn verblijfsrecht afhankelijk van het gastgezin. De richtlijn vermeld niet of het mogelijk is om tijdens de geldigheid van de verblijfsvergunning van gastgezin te veranderen. Hetzelfde geldt voor de vrijwilligers en stagiairs die op grond van de Onderzoekersen studentenrichtlijn in een lidstaat verblijven.

De positie van hoger opgeleide derdelanders is in dit opzicht gunstiger. De blauwe-kaarthouder heeft in geval van werkloosheid gedurende de geldigheidsduur van zijn verblijfsvergunning een periode van drie maanden om een andere baan te zoeken die voldoet aan de voorwaarden van de richtlijn. ${ }^{80}$ Bovendien kunnen gedurende deze periode onvoldoende middelen van bestaan geen reden zijn om de vergunning in te trekken. ${ }^{81}$ De onderzoeker heeft een periode van negen maanden na voltooiing van de onderzoeksactiviteit om werk te zoeken of een bedrijf op te richten. ${ }^{82}$ De arbeidsmigrant die is uitgezonden in het kader van 
overplaatsing binnen een onderneming heeft binnen het kader van de aan hem verleende verblijfsvergunning geen mogelijkheid om van werkgever te veranderen, omdat hij dan niet meer voldoet aan de voorwaarden die van toepassing zijn op deze vergunning.

\subsection{Duur verblijfsrecht en permanent verblijf}

Een laatste facet met betrekking tot de regulering van het verblijfsrecht dat van invloed is op de kwetsbaarheid voor uitbuiting is de duur van het verblijfsrecht en zicht op permanent verblijf. Tijdelijk verblijf maakt migranten kwetsbaarder voor uitbuiting, omdat een tijdelijk verblijfsrecht afhankelijk is van het blijven voldoen aan voorwaarden. Pas op het moment dat een migrant een permanente verblijfsvergunning heeft, hangt het verblijfsrecht niet meer af van het voldoen aan voorwaarden als beschikken over werk en voldoende inkomen. Verder zijn de rechten van een migrant met tijdelijk verblijf vaak beperkt in vergelijking met de rechten van een migrant met permanent verblijf. ${ }^{83}$ Uit onderzoek blijkt voorts dat sommige werkgevers misbruik maken van de tijdelijkheid van het verblijf van een migrant door niet al het loon uit te betalen aan een migrant die verplicht is terug te keren naar zijn land van herkomst. ${ }^{84}$

Arbeidsgerelateerde migratie wordt al decennia lang beschouwd als een vorm van tijdelijke migratie, met name bedoeld om tekorten in het nationale arbeidsaanbod op te vullen zolang dit nodig is. ${ }^{85}$ In alle huidige EU-migratie-instrumenten, waaronder de instrumenten die arbeidsgerelateerde migratie reguleren, is vastgelegd dat het initiële verblijfsrecht dat een derdelander kan verwerven voor een bepaalde tijd is. De duur van het initiële verblijf, de mogelijkheid om het verblijf te verlengen en de totale mogelijke verblijfsduur verschillen aanzienlijk per verblijfssoort. Verblijfscategorieën zoals au pairs, stagiairs en vrijwilligersprogramma's zijn opgezet als vormen van tijdelijk verblijf met korte duur. In de Onderzoekers- en studentenrichtlijn wordt de verblijfsduur voor elk van deze categorieën bepaald. Deze verblijfsgronden zijn allemaal bedoeld om een bepaalde ervaring op te doen en niet als een volwaardige baan. Het beperken van de verblijfsduur van deze vormen van migratie kan ertoe bijdragen dat deze verblijfsmogelijkheden ook door migranten worden gebruikt als een eenmalige ervaring. Tegelijkertijd is vaak de vraag van de gastentiteit (bijvoorbeeld het gastgezin of het bedrijf dat stagiairs aanneemt) niet tijdelijk. Dat betekent dat de tijdelijkheid van het verblijf van de derdelandermigrant gebruikt kan worden door de gastentiteit om te profiteren van goedkope tijdelijke krachten. Ten aanzien van het ver-

Zie bijvoorbeeld M. Ruhs \& P. Martin, Numbers vs. Rights: Trade-Offs and Guest Worker Programs, IMR 2008, 1, p. 250-251; R. Zapata-Barrero, R. Faúndez García \& E. Sanchez-Montijano, Circular Temporary Labour Migration: Reassessing Established Public Policies, International Journal of Population Research 2012, p. 6; J.H. Carens, The Ethics of Immigration, Oxford: University Press 2010, p. 110.

84 FRA 2015, p. 49.

85 S. Castles, The guest worker in Western Europe: An obituary, The International Migration Review 1986, 4, p. 761-778. Zie ook CDMG, Temporary migration for employment and training purposes, 1996. 
blijf als au pair laat onderzoek zien dat er sprake is van misbruik. ${ }^{86}$ Het risico op uitbuiting van au pairs en stagiairs is ook door de Europese Commissie onderkend. ${ }^{87}$

Ook seizoensarbeid wordt geassocieerd met uitbuiting. ${ }^{88}$ Voor deze sector blijkt dat juist de tijdelijkheid bijdraagt aan het vergroten van de kwetsbaarheid voor uitbuiting. ${ }^{89}$ De tijdelijkheid van dit werk vloeit in eerste instantie voort uit het seizoensgebonden karakter van het werk en niet uit de keus van een werknemer. Het tijdelijke karakter van seizoensarbeid wordt onderstreept in de preambule van de Richtlijn Seizoensarbeid: 'De maximale duur van het verblijf moet door de lidstaten worden vastgesteld en beperkt blijven tot een periode van vijf tot negen maanden, die samen met de definitie van seizoensarbeid ervoor moet zorgen dat het werk echt seizoensgebonden is.' Seizoenswerk is echter per definitie een vorm van terugkerende arbeid en het is niet uitgesloten dat een seizoensarbeider jaar na jaar terugkomt. Circulaire migratie, waarbij een migrant afwisselend een periode werkt in een gastland en teruggaat naar zijn land van herkomst, wordt wel gezien als een win-win-winsituatie. ${ }^{90}$ Het voorziet in de behoefte van werkgevers in de gaststaat aan tijdelijk personeel; het betekent terugvloeiende inkomsten naar het land van oorsprong van de migrant, en de migrant zelf verwerft inkomsten die hij in zijn land van oorsprong niet kan verwerven. Circulaire migratie betekent echter ook een gedeelte van het jaar geen inkomsten, geen verblijfsrecht en dus geen mogelijkheid om een volwaardig bestaan in de gaststaat op te bouwen. Voor migranten is dit (op den duur) niet een ideale situatie. ${ }^{91}$

Overplaatsingen binnen een onderneming op grond van de ICT-richtlijn is ook tijdelijke migratie. ${ }^{92}$ Deze categorie derdelanders is echter beschermd tegen werkloosheid door de voorwaarde dat de derdelander na afloop van de detachering zal worden overgeplaatst naar een andere entiteit in een derde land. ${ }^{93}$ Alleen de Blauwe Kaart-richtlijn biedt perspectief op een langer verblijf. Hoewel deze richtlijn bepaalt dat de lidstaten de geldigheidsduur van de verblijfskaart kunnen bepalen tussen één en vier jaar, kan het verblijfsrecht na deze periode worden verlengd. ${ }^{94}$

Pas nadat een derdelander een permanent verblijfsrecht heeft verworven, is zijn verblijf niet langer afhankelijk van het voldoen aan voorwaarden als voldoende inkomen of het hebben van een baan. Carens meent dat als na een aantal jaren

J.M.D. Schans, M. Galloway \& L. Lansang, Au pairs in Nederland. Culturele uitwisseling of arbeidsmigratie?, WODC Cahier 2014-2.

$87 \operatorname{COM}(2013) 151$ final, p. 3.

88 FRA 2015, p. 49.

89 Zie bijvoorbeeld Rijken 2015; E. Consterdine \& S. Samuk, Temporary Migration Programmes: the Cause or Antidote of Migrant Worker Exploitation in UK Agriculture, International Migration \& Integration 2018, 19, p. 1005-1020.

90 P. Wickramasekara, Circular migration: A Triple Win or a Dead End, Global Uinon Research Network, ILO 2011.

91 Wickramasekara 2011. p. 23.

92 Preambule 17-18, Richtlijn 2014/66/EU.

93 Preambule 19, Richtlijn 2014/66/EU.

94 Artikel 16 Richtlijn 2009/50/EG. 
het tijdelijk verblijf niet eindigt, er een moreel recht op permanent verblijf ontstaat. ${ }^{95}$ Hij gaat hierbij uit van een periode van vijf jaar. De Richtlijn Langdurig ingezetenen bepaalt dat na een periode van vijf jaar rechtmatig en ononderbroken verblijf bepaalde categorieën derdelanders recht hebben op permanent verblijf. ${ }^{96}$ Derdelanders met een verblijfsrecht van tijdelijke aard op het moment van aanvraag zijn echter uitgesloten van de reikwijdte. Ook telt verblijf van tijdelijke aard niet mee voor de periode van vijf jaar legaal verblijf. ${ }^{97}$ De richtlijn bevat geen uitputtende lijst met soorten verblijf die kwalificeren als verblijf van tijdelijke aard, maar verblijf voor seizoensarbeid, als au-pair of als gedetacheerde werknemer wordt wel expliciet genoemd. Voor deze derdelanders is er dus geen zicht op permanent verblijf.

\section{Bescherming van migranten in een uitbuitingssituatie}

In de vorige paragraaf is onderzocht of de wijze waarop toelating en verblijf van derdelanders naar de EU in het EU-recht zijn gereguleerd, bijdraagt aan de bescherming tegen uitbuiting of juist kwetsbaar maakt voor uitbuiting. In deze paragraaf komt de deelvraag aan bod of, en zo ja, op welke wijze het EU-migratierecht bescherming biedt aan derdelanders die zich in een uitbuitingssituatie bevinden. Het bieden van bescherming aan migranten in een uitbuitingssituatie kan een aansporing zijn om zich aan de uitbuiting te onttrekken. ${ }^{98}$ Hierbij kan gedacht worden aan een recht op voorzieningen, zoals verblijfsrecht en recht op vordering van achterstallig loon. ${ }^{99}$ Daarnaast kan strafrechtelijke vervolging van de werkgever bescherming bieden. Een derdelander die geen recht heeft op bescherming, zal bij het melden van een uitbuitingssituatie het aanmerkelijke risico lopen dat hij zonder werk, zonder inkomen en zonder verblijfsrecht achterblijft. Een juridisch kader waarin het recht op bescherming is vastgelegd, is een eerste stap richting bescherming. Voorts is de wijze waarop de toegang tot het recht is geregeld van groot belang. ${ }^{100}$

Meest kwetsbaar voor uitbuiting zijn migranten zonder rechtmatig verblijf. Het ontbreken van een legale verblijfsstatus vergroot de afhankelijkheid van de werkgever en versterkt de machtspositie van de werkgever ten opzichte van de arbeidsmigrant. Een arbeidsmigrant in een irreguliere situatie is vaak bang terug-

95 Carens 2010, p. 113

96 Artikel 4 lid 1 Richtlijn 2003/109/EG.

97 Artikel 3 lid 2 (e) en artikel 4 lid 2 Richtlijn 2003/109/EG.

98 N. Tielbaard, M. van Meeteren \& X. Commandeur, Slachtoffer van arbeidsuitbuiting? Een kwalitatieve studie naar ideaaltypische trajecten die leiden tot zelfidentificatie als slachtoffer van mensenhandel, Tijdschrift voor Criminologie 2016, 2, p. 47.

99 FRA 2015, p. 73 e.v.; FRA 2019, p. 77 e.v.; E. Dewhurst, The right of irregular migrants to back pay: The spectrum of protection in international, regional, and national legal systems, in: $C$. Costello \& M. Freedland, Migrants at work. Immigration and Vulnerability in Labour Law, Oxford: University Press 2014, p. 216-238.

100 De effectiviteit van een juridisch kader dat bescherming biedt is van meer factoren afhankelijk en hangt onder meer samen met hoe migranten hun kans op genoegdoening (financiële compensatie en/of bestraffing van uitbuiter) inschatten als ze een werkgever aangeven: FRA 2019, p.44. 
gestuurd te worden naar het land van herkomst en accepteert de arbeidsomstandigheden omdat hij geen alternatieven ziet. ${ }^{101}$ De Werkgeverssanctierichtlijn biedt deze groep derdelanders enige bescherming. Het hoofddoel van deze richtlijn is echter het tegengaan van illegale immigratie en illegale tewerkstelling. Volgens de preambule is een cruciale aantrekkingsfactor voor illegale immigratie de mogelijkheid om werk in de EU te verwerven zonder de vereiste wettelijke status. ${ }^{102}$ De EU-wetgever is van mening dat het middelpunt van maatregelen ter bestrijding van illegale immigratie een algemeen verbod moet zijn op de tewerkstelling van derdelanders zonder legaal verblijf, in combinatie met sancties tegen werkgevers die deze verplichting schenden. ${ }^{103}$

Naast de maatregelen ter bestrijding van illegale immigratie bevat de Werkgeverssanctierichtlijn maatregelen die illegale migranten bescherming moeten bieden. Op grond van de Werkgeverssanctierichtlijn zorgen lidstaten ervoor dat werkgevers aansprakelijk zijn voor de achterstallige betalingen van alle uitstaande beloningen, inclusief een bedrag dat gelijk is aan belastingen en socialezekerheidsbijdragen die de werkgever zou hebben betaald in het geval dat de onderdaan van een derde land legaal was tewerkgesteld. ${ }^{104}$ Eventuele kosten die voortvloeien uit het sturen van betalingen naar het land waarnaar de derdelander is teruggekeerd, moeten door de werkgever worden betaald.

Illegale tewerkstelling moet op grond van artikel 9 van de Werkgeverssanctierichtlijn strafbaar worden gesteld. Als het gaat om illegale tewerkstelling die gepaard gaat met arbeidsgerelateerde uitbuiting of om de illegale tewerkstelling van een minderjarige, kan de derdelander in het kader van een strafprocedure een verblijfsrecht van beperkte duur krijgen. ${ }^{105}$ De regeling voor het verkrijgen van een (tijdelijk) verblijfsrecht is beperkt tot onrechtmatig verblijvende derdelanders die kunnen worden aangemerkt als slachtoffers van arbeidsuitbuiting in een mate die vergelijkbaar is met mensenhandel. ${ }^{106}$ Deze verblijfsvergunning is echter uitdrukkelijk bedoeld ter facilitering van het strafproces tegen de betrokken werkgever. Deze constructie is gebaseerd op de regeling van het tijdelijke verblijfsrecht bij meewerken aan een strafprocedure wegens mensenhandel. ${ }^{107}$ Aan slachtoffers van mensenhandel zonder verblijfstitel die meewerken aan een nationale strafprocedure kan ook een tijdelijk verblijfsrecht worden verleend. ${ }^{108}$ Lidstaten dienen in hun nationale wetgeving de voorwaarden te bepalen waaronder zij een vergunning kunnen verlenen voor de duur van de nationale strafprocedure.

101 FRA 2019, p. 67.

102 Preambule 2, Richtlijn 2009/52/EG.

103 Preambule 3, Richtlijn 2009/52/EG.

104 Artikel 6 Richtlijn 2009/52/EG.

105 Artikel 13 lid 4 jo. artikel 9 lid 1 (c en e) Richtlijn 2009/52/EG.

106 Arbeidsgerelateerde uitbuiting is in artikel 2 lid 1 Richtlijn 2009/52/EG gedefinieerd als: 'arbeidsvoorwaarden en -omstandigheden, ook die voortvloeien uit discriminatie op grond van geslacht of anderszins, waarin er een opvallende wanverhouding bestaat in vergelijking met de arbeidsvoorwaarden en -omstandigheden die gelden voor legaal tewerkgestelde werknemers, waardoor bijvoorbeeld de gezondheid en veiligheid van de werknemers in gevaar worden gebracht, en die indruisen tegen de menselijke waardigheid'. Zie ook Richtlijn 2004/81/EG.

107 Zie artikel 8 Richtlijn 2004/81/EG.

108 Zie artikel 8 Richtlijn 2004/81/EG. 
Bovendien moeten de lidstaten, als een vergunning is verleend, de voorwaarden definiëren waaronder de duur van deze tijdelijke verblijfsvergunning kan worden verlengd totdat de derdelander de betaling van de achterstallige vergoeding heeft ontvangen. ${ }^{109}$ De regulering van een verblijfsrecht is echter niet alleen beperkt tot situaties van zware uitbuitende arbeidsomstandigheden, het is ook een facultatieve clausule die de lidstaten veel vrijheid laat en alleen voorziet in een tijdelijk verblijfsrecht voor de duur van nationale strafprocedures en mogelijk de afwikkeling van achterstallige betalingen.

De Richtlijn Seizoensarbeid, de ICT-richtlijn en de Onderzoekers- en studentenrichtlijn bevatten enkele bepalingen die derdelanders dienen te beschermen als hun verblijfsvergunning is ingetrokken onder andere omdat de werkgever is bestraft wegens zwart werk of illegale tewerkstelling. Bij een beslissing tot intrekking moet rekening gehouden worden met de specifieke omstandigheden van het geval, de belangen van de werknemer en het evenredigheidsbeginsel. ${ }^{110}$ De Richtlijn Seizoensarbeid biedt verdergaande mogelijkheden om de vergunning in te trekken, maar ook verdergaande bescherming ingeval de vergunning wordt ingetrokken. Deze richtlijn schrijft voor dat de lidstaten ervoor dienen te zorgen dat de werkgever 'aansprakelijk wordt gesteld voor de betaling van een vergoeding aan de seizoenarbeider volgens de procedures van het nationale recht. De aansprakelijkheid dekt alle resterende verplichtingen die de werkgever had moeten nakomen indien de vergunning met het oog op seizoenarbeid niet was ingetrokken. ${ }^{111}$ De richtlijn biedt echter geen recht op verblijf in afwachting van de nakoming van deze verplichtingen door de werkgever.

Als het gaat om het faciliteren van toegang tot de verleende rechten, bevat de Werkgeverssanctierichtlijn enkele bepalingen die de toegankelijkheid moeten bevorderen. Lidstaten moeten effectieve mechanismen creëren die illegaal verblijvende derdelanders in staat stellen een klacht in te dienen tegen hun werkgever. ${ }^{112}$ Derden met een legitiem belang bij het waarborgen van de naleving van de richtlijn, zoals vakbonden, moeten namens of ter ondersteuning van derdelanders kunnen deelnemen aan civiele of administratieve procedures waarin is voorzien op basis van de richtlijn.

De pakkans van malafide werkgevers dient te worden vergroot door effectieve en adequate inspecties om de tewerkstelling van illegaal verblijvende onderdanen van derde landen te kunnen controleren. ${ }^{113}$ Verder schrijft de Werkgeverssanctierichtlijn voor dat illegaal tewerkgestelde derdelanders voorafgaand aan de uitvoering van de terugkeerbeslissing objectief geïnformeerd worden over hun rechten met betrekking tot nabetaling en een tijdelijk verblijfsrecht. ${ }^{114}$

109 Artikel 6 lid 5 Richtlijn 2009/52/EG.

110 Zie artikel 9 lid 5 Richtlijn 2014/36/EU; artikel 9 lid 6 Richtlijn 2014/66/EU; artikel 21 lid 7 Richtlijn 2018/801/EU. De ICT-richtlijn en de Onderzoekers- en studentenrichtlijn noemen niet expliciet de belangen van de werknemer/derdelander.

111 Artikel 17 lid 2 Richtlijn 2014/36/EU.

112 Artikel 13 Richtlijn 2009/52/EG.

113 Artikel 14 Richtlijn 2009/52/EG.

114 Artikel 6 lid 2 Richtlijn 2009/52/EG. 
De toegankelijkheid van de bescherming die aan derdelanders op basis van de definitieve tekst van de Werkgeverssanctierichtlijn wordt geboden, is op verschillende punten afgezwakt ten opzichte van de bescherming waarin de conceptversie voorzag. ${ }^{115}$ Dit geldt bijvoorbeeld voor de wijze waarop een loonvordering moet worden geregeld en de betrokkenheid van de overheid hierbij, de termijn waarbinnen een loonvordering moet worden ingesteld (van zes naar drie maanden) en de omzetting van een recht op een tijdelijk vergunning in geval van een strafrechtelijke procedure tegen een werkgever naar een facultatieve bepaling. ${ }^{116}$ De inbreng van Nederland op dit punt kwam voort uit de vrees illegale tewerkstelling aantrekkelijk te maken. ${ }^{117}$

Het sluitstuk van een geloofwaardig migratiebeleid is volgens de EU-wetgever een effectief terugkeerbeleid. ${ }^{118}$ In beginsel zal aan een irregulier verblijvende migrant samen met de verplichting het grondgebied van de lidstaten te verlaten (het zogenoemde terugkeerbesluit) een inreisverbod opgelegd moeten worden. ${ }^{119}$ Het inreisverbod als gevolg van onrechtmatig verblijf, zoals voorgeschreven door de Terugkeerrichtlijn, kan een extra belemmering vormen voor illegaal verblijvende derdelanders om misbruik in een werksituatie te melden. ${ }^{120}$

\section{Normen die uitbuiting tegengaan}

De derde vorm van invloed is het stellen van normen die uitbuiting moeten voorkomen. In het kader van migratiewetgeving gaat het dan om een recht op gelijke behandeling van migrerende werknemers met eigen burgers. Gelijke behandeling met eigen burgers op het gebied van arbeidsvoorwaarden dient een tweeledig doel. ${ }^{121}$ Ten eerste moet het de eigen bevolking beschermen tegen sociale dumping en oneerlijke concurrentie. Sociale dumping wil zeggen dat de arbeidsvoorwaarden van de eigen bevolking onder druk staan door de aanwezigheid van arbeidsaanbod van migranten die bereid zijn om tegen minder gunstige voorwaarden hetzelfde werk te doen. Ten tweede moet het de migrerende werknemers beschermen tegen uitbuiting. Deze zienswijze is ook verwoord in de preambule van de Richtlijn Verblijf en werk. ${ }^{122}$ Uit de definitie van uitbuiting die in dit artikel wordt gebruikt, volgt dat ongelijke behandeling op zichzelf al een vorm van uitbuiting is.

115 Zie P. Krop, T. de Lange \& M. Tjebbes, Richtlijn 2009/52/EG. Sancties tegen werkgevers van illegaal verblijvende derdelanders, Migrantenrecht 2009, 8, p. 336-346.

116 Krop, De Lange \& Tjebbes 2009, p. 344-345.

117 Krop, De Lange \& Tjebbes 2009, p. 344.

$118 \operatorname{COM}(2014) 199$ final, p.2.

119 Artikel 6 lid 1 jo. artikel 11 lid 1 Richtlijn 2008/115/EG.

120 Zie bijvoorbeeld Dewhurst 2014, p. 217-218.

121 K. Groenendijk, Equal treatment of workers from third countries: The added value of the Single Permit Directive, in P. Minderhoud \& T. Strik (red.), The Single Permit Directive: Central Themes and Problem Issues, Oisterwijk: Wolf Legal Publishers 2015, p. 23.

122 Preambule 19, Richtlijn 2011/98/EU. 
In de voorgaande paragrafen is al geconstateerd dat op verschillende gebieden derdelanders onderling niet gelijk behandeld worden. Dit geldt voor het stellen van een inkomensvereiste, de duur van de verblijfsvergunning, de mogelijkheid tot verlenging, toegang tot permanent verblijf, toegang tot werk, en het recht om van werkgever te wisselen. De ongelijke behandeling van derdelanders onderling op diverse terreinen is met name problematisch voor de zwakkere categorie seizoensarbeiders en au pairs. ${ }^{123}$ In deze paragraaf wordt gekeken naar de gelijke behandelingsrechten die als zodanig in de diverse richtlijnen zijn opgenomen en moeten voorzien in een recht op gelijke behandeling met de eigen burgers. In het geval dat er geen recht op gelijke behandeling wordt toegekend, is het de vraag of er wel minimumnormen worden gesteld.

Een algemeen verbod op discriminatie is opgenomen in artikel 21 lid 1 Handvest. Artikel 21 lid 2 bevat een verbod op discriminatie naar nationaliteit binnen de werkingssfeer van de verdragen. Op grond van artikel 31 van het Handvest heeft iedere werknemer recht op rechtvaardige en billijke arbeidsomstandigheden.

De EU-migratierichtlijnen bevatten een recht op gelijke behandeling op verschillende terreinen. Op de eerste plaats bevatten de richtlijnen normen ten aanzien van gelijke behandeling met betrekking tot arbeidsvoorwaarden. Een tweede terrein ziet op rechten op het gebied van sociale zekerheid en sociale bijstand. Een derde categorie rechten heeft betrekking op toegang tot goederen en diensten. Hierbij kan bijvoorbeeld gedacht worden aan toegang tot huisvesting, gezondheidszorg en onderwijs. Er bestaan aanzienlijke verschillen ten aanzien van de gelijke behandelingsrechten van derdelanders die in de verschillende migratierichtlijnen zijn neergelegd. ${ }^{124}$

De Richtlijn Verblijf en werk bevat volgens artikel 1 een gemeenschappelijk pakket aan rechten voor legaal op het grondgebied verblijvende werknemers gebaseerd op gelijke behandeling met de eigen burgers. De richtlijn volgt echter de gefragmenteerde benadering van de regulering van migratie door verschillende verblijfscategorieën van het toepassingsgebied uit te sluiten, zoals seizoensarbeiders, binnen een onderneming overgeplaatste personen en au pairs. ${ }^{125}$ Verder zijn nog enkele andere verblijfscategorieën uitgesloten, zoals personen die internationale bescherming genieten en langdurig ingezetenen. ${ }^{126}$ Alle migratierichtlijnen, behalve de Gezinsherenigingsrichtlijn, ${ }^{127}$ bevatten echter zelf ook een clausule met betrekking tot gelijke behandeling. De sterkste bescherming wordt gebo-

123 M. Zoeteweij, The Principle of (In)equality in EU Labour Migration Law, European (Legal) Studies on-line papers 2016, 3.

$124 \mathrm{~K}$. de Vries, Integratie en de onzekere verwachting van gelijke behandeling van derdelanders. Great Expectations, Asiel en Migrantenrecht 2017, 6/7, p. 260.

125 Artikel 3 lid 2 (d) Richtlijn 2011/98/EU.

126 Artikel 3 lid 2 (g, i) Richtlijn 2011/98/EU.

127 Richtlijn 2003/86/EG voorziet alleen in een recht op gelijke behandeling met de sponsor als het gaat om toegang tot de arbeidsmarkt. 
den aan langdurig ingezeten migranten ${ }^{128}$ en vluchtelingen. ${ }^{129}$ Ook de rechten die worden geboden aan de blauwe-kaarthouders ${ }^{130}$ zijn sterker dan de rechten die worden gegarandeerd in de Richtlijn Verblijf en werk. ${ }^{131}$ Wat betreft basisarbeidsvoorwaarden zoals beloning, ontslag, werkuren, verlof en vakantie, gezondheidsen veiligheidseisen op de werkplek voorzien alle werkgerelateerde richtlijnen in een recht op gelijke behandeling. Bovendien hebben arbeidsmigranten het gelijke recht om te staken en industriële actie te ondernemen. ${ }^{132}$ Er wordt verschil gemaakt als het gaat om toegang tot huisvesting, scholing en studiefinanciering, toegang tot goederen en diensten, belastingvoordelen en sociale bijstand. ${ }^{133}$ De meest kwetsbare groep als het gaat om recht op gelijke behandeling wordt gevormd door stagiairs, vrijwilligers en au pairs. Zij hebben alleen recht op gelijke behandeling met onderdanen van de gaststaat voor zover zij een arbeidsverhouding hebben. Als de grondslag waarop zij werkzaamheden verrichten echter niet beschouwd wordt als een arbeidsverhouding, hebben ze alleen recht op gelijke behandeling met betrekking tot toegang tot goederen en diensten. ${ }^{134}$ De richtlijn voorziet niet in richtlijnen of criteria om te beslissen of werk als stagiair, vrijwilliger of au pair moet worden aangemerkt als een arbeidsverhouding of niet. Deze beslissing wordt overgelaten aan de beoordelingsmarge van de lidstaten.

Voor de meeste migratierichtlijnen omvat het recht op gelijke behandeling wel socialezekerheidsrechten op basis van hun status als werknemer, maar geen sociale bijstand. Alleen langdurig ingezetenen en personen die internationale bescherming genieten kunnen aanspraak maken op sociale bijstand, waarvoor geen bijdrage is betaald. Voor andere verblijfstypes kan afhankelijkheid van het sociale bijstandsstelsel van de gaststaat een reden zijn om de verblijfsvergunning in te trekken. Dit is bijvoorbeeld van toepassing op gezinshereniging ${ }^{135}$ en verblijf op grond van de Onderzoekers- en studentenrichtlijn. ${ }^{136}$

Een laatste punt met betrekking tot gelijke behandeling is het recht op gezinshereniging. Het recht op gezinsleven en een verdergaand recht op gezinshereniging kan beschouwd worden als onderdeel van sociale rechten en van wezenlijk belang voor het welbevinden van een migrerende werknemer. Het belang van gezinsle-

128 Artikel 11 Richtlijn 2003/109/EG.

129 Zie artikelen 26-30 Richtlijn 2011/95/EU. Voor personen die een vorm van subsidiaire bescherming hebben gekregen in plaats van bescherming als vluchteling, geldt ten aanzien van het recht op sociale bijstand de mogelijkheid om deze te beperken tot de meeste fundamentele prestaties (artikel 29 lid 2).

130 Artikel 14 Richtlijn 2009/50/EG.

131 Artikel 12 Richtlijn 2011/98/EU.

132 Zie bijvoorbeeld artikel 21 lid 1 (b) Richtlijn 2011/98/EU; artikel 23 lid 1 (b) Richtlijn 2014/36/ EU.

133 Groenendijk 2015, p. 34-35. Zo oordeelde het Hof van Justitie in de zaak Kamberaj dat een langdurig ingezetene recht kan hebben op huursubsidie onder dezelfde voorwaarden als de eigen ingezetenen op grond van artikel 11 lid 1 (d) Richtlijn 2003/109/EG: HvJ EU 24 april 2012, C-571/10 (Kamberaj/Italië).

134 Artikel 22 lid 3 en 4 Richtlijn 2016/801/EU.

135 Artikel 7 lid 1 (c) jo. artikel 16 lid 1 Richtlijn 2003/86/EG.

136 Artikel 7 lid 1 (e) Richtlijn 2016/801/EU. 
ven voor een werknemer in het algemeen is onder andere te vinden in artikel 27 van het Europees Sociaal Handvest, waarin het recht op het kunnen combineren van werk met gezinsverantwoordelijkheden is vastgelegd. Specifiek ten aanzien van migrerende werknemers bepaalt het Internationaal Verdrag ter bescherming van de rechten van migrerende werknemers in artikel 44 lid 2 dat staten maatregelen dienen te nemen om gezinshereniging te faciliteren.

In het kader van vrij werknemersverkeer en gelijke behandeling binnen de EU oordeelde het Europees Hof van Justitie al in 1986 dat gezinshereniging valt onder 'sociaal voordeel' als bedoeld in artikel 7 lid 2 van Verordening 1612/68. ${ }^{137}$ Het recht op gelijke behandeling omvatte daarom volgens het Hof ook het recht op gezinshereniging onder dezelfde voorwaarden die gelden voor de nationale werknemers. Als het gaat om het recht op gezinshereniging voor derdelander werknemers valt echter op dat voor de migratiedoelen die bedoeld zijn voor hoogopgeleide derdelanders wel een recht op gezinshereniging bestaat, zoals de blauwe-kaarthouders, ${ }^{138}$ de onderzoekers ${ }^{139}$ en de binnen een onderneming gedetacheerde derdelanders. ${ }^{140}$ Voor gezinsleden van werknemers die niet vallen onder deze specifieke regelingen gelden de standaardvoorwaarden van de Gezinsherenigingsrichtlijn. Deze richtlijn sluit derdelanders met een verblijfsrecht dat korter is dan een jaar en die geen zicht hebben op permanent verblijf uit van het recht op gezinsherenging. ${ }^{141}$ Dat geldt dus onder andere voor seizoensarbeiders.

\section{Conclusie}

In dit artikel is onderzocht wat de invloed is van de EU-migratiewetgeving op uitbuiting van derdelanders. Er zijn drie vormen van invloed te onderscheiden. Ten eerste kan de wijze waarop toelating en verblijf zijn gereguleerd de kwetsbaarheid voor uitbuiting vergroten of verkleinen. Ten tweede kan EU-migratiewetgeving bescherming bieden aan derdelanders in een uitbuitingssituatie. Ten slotte stelt EU-migratiewetgeving normen voor de behandeling van derdelanders die uitbuiting moeten voorkomen.

Ten aanzien van de wijze waarop toelating en verblijf van derdelanders zijn gereguleerd, kan geconcludeerd worden dat EU-wetgeving in bepaalde opzichten bijdraagt aan de bescherming van migranten tegen uitbuiting. De EU-migratiewetgeving creëert een systeem van voorwaarden voor toegang tot en verblijf op het EU-grondgebied dat diverse mogelijkheden voor legale migratie biedt. Dit systeem biedt rechtszekerheid en dat versterkt de positie van een migrant en maakt hem minder kwetsbaar voor uitbuiting. Echter, de wijze van regulering van toegang en verblijf kent voor enkele verblijfsdoelen ook aspecten die toegang en verblijf onzeker maken. Dit vergroot de kwetsbaarheid voor uitbuiting. Hierbij moet 
met name gedacht worden aan beperkingen met betrekking tot de toegang tot de arbeidsmarkt, gebondenheid aan een werkgever door de voorwaarde van voldoende inkomsten of een arbeidscontract, en de tijdelijkheid van het verblijf.

Aan derdelanders in een uitbuitingssituatie wordt in theorie wel enige bescherming geboden. Dit geldt zowel voor illegaal verblijvende derdelanders als voor bijvoorbeeld seizoensarbeiders. Ten aanzien van het faciliteren van de toegang tot deze rechten schiet de EU-wetgeving echter tekort. Het is duidelijk dat op dit punt het bestrijden van illegale migratie en het controleren van migratie voorrang hebben gekregen boven bescherming van migranten.

De EU-migratiewetgeving bevat normen voor de behandeling van derdelanders die uitbuiting moeten voorkomen. Voor alle legaal verblijvende derdelanders die werkzaam zijn in een lidstaat geldt een recht op gelijke behandeling met de eigen burgers van die lidstaat op het gebied van de standaardarbeidsvoorwaarden en socialezekerheidsrechten verbonden aan de status van werknemer. Er is er geen (volledig) recht op gelijke behandeling als het gaat om overige sociale voordelen. De verschillen tussen richtlijnen zijn wat dat betreft aanzienlijk. De minst gunstige behandeling geldt in dit opzicht voor au pairs, vrijwilligers en stagiairs die niet werkzaam zijn op grond van een arbeidsverhouding.

De migratiewetgeving van de EU kent meerdere doelen. Om bepaalde vormen van migratie te stimuleren en andere vormen van migratie in te dammen wordt er onderscheid gemaakt tussen verschillende categorieën derdelanders. Hierdoor is er een grote mate van ongelijkheid tussen diverse vormen van migratie en migranten gecreëerd. Voor bepaalde categorieën, zoals hooggekwalificeerde werknemers en onderzoekers, biedt de EU-migratiewetgeving kansen en bescherming tegen uitbuiting. Voor andere categorieën, zoals seizoensarbeiders, asielzoekers of irregulier verblijvende migranten, is de bijdrage van de EU-migratiewetgeving aan de bescherming tegen uitbuiting beperkter of werkt ze zelfs contraproductief. 